\title{
Competencies, Skills and Training Needs of Hospitality Firm Employees in Oman towards Promotion: An Inquiry
}

\author{
Roland Getaruelas
}

\begin{abstract}
The aim of this study is to find out the necessary competencies, skills and trainings that hospitality employees must have in order for them to accelerate in advance into key position. This is to measure the capabilities of the employee on how they should perform and what are the expected output when they are promoted in to middle post. It is empirical that when you hold a middle position you must be equipped by couple of skills and upgrade it from time to time by attending trainings and seminars, so that the knowledge and information are attune and innovative. Findings revealed in this study that trainings and development, attitude, education as well as previous working experience in the same industry were all rated as important, it can make an individual to be more qualified, competent and effective to hold position in the hospitality industry.
\end{abstract}

Index Terms: Leader, Competency, Skills, Managerial Position, Training needs, key Position, Hospitality Industry.

\section{INTRODUCTION}

Now a day's men and women are having equal opportunity whenever industry you are, both gender are dynamic and equipped of those expected capabilities, likewise competition for promotion in every organization is demanded to be competitive. It is essential for an employee to be competitive among others and capable of doing a multi-tasking work and ability perform as a problem solver, critical analysis, innovative and output oriented. Therefore it empirical that an employee must have both basic and advance necessary things like; education, trainings, seminars, attitude and work experience to be competitive and fit for the position. Exploring your strengths in the working environment will define what really you can do and how far you can be as your skills and competencies must will bring you at your best. Having a good skills, trainings, and education are requirements for success in your current and future job role in industry. Competencies blended with your own knowledge and good character to produce a good performance output that may apply across job role functions in different forms these are very vital in advance promotion.

Oman's rapidly growing tourism industry which attracts businessmen to build more restaurants and hotels in order to support the demand.
Thus, as number of tourism influx in the country's increasing yearly, it brings opportunity to so many jobseekers. However current employees are facing career competition inside the organization, due to management qualification requirement, such as education, training and seminars attended. in Muscat alone numbers of restaurants and hotels are sprouting in the heart of the city and near beaches where 80 percent of their workforce are expat, facing huge competition. Companies are requiring tough competencies for you to get a position, thus employees are updating their skills, knowledge and even education.

According to Dubrin (2015) that being resultsoriented the management process approach to training concerns the provision of opportunities for managers to become acquainted with principles, concepts and techniques, which are useful in improving their efficiency and effectiveness. Which means that skills and competencies of a leader is very vital to the success of the organization. Leaders must continue in learning thru seminars, training and even to considering graduate studies. Development should not be stopped in order to update and upgrade your skills from time to time.

The aim of this study was to determine what type of competencies, skills and training needs in order for them to advance in to managerial position. To those employees currently working in a hospitality industry. The researcher chose those employees that are currently working in the following hospitality facility: Shangri-La Hotel, Sheraton Hotel, Radisson blue hotel, Chillis Restaurant, Kabayan Restaurant and Pizza hut. This in order

\section{REVIEW OF RELATED LITERATURE}

Similar in the study of Purcell (993) the training needs of the hospitality employees which resulted that manager and supervisor must be able to aware how to deal with the external forces like globalization, technology advancement and cultural diversity. The hospitality industry is now improving its standard quickly from its traditional style, when it comes to strategy, technology application and even management style. Therefore, in order to be dynamic and attune to the new culture growing within the organization. Future leaders must be aware in this very important factors, be proactive to the above-mentioned and continue learnings from new things to adopt a culture of modernization. 
In the previous study of Wessel ( 2017) he found out that the most important four major factor of an employee in tourism industry are; First characteristic, in his findings that when the company hires an individual to become part of their organization it is not only experience but also personality matters. According the respondents characteristic is something that anybody cannot be taught or trained. A person must have a good characteristic or personality, when the time that he or she will experience tough situation in his job he might use this factor to manage the job well. Second, it was found put that those respondents who are managers were either young or old ages are holding diploma or degree, therefore if you have education undergraduate or graduate degree it brings you a piece of pie in the promotional opportunity. Once you're educated it will support your knowledge and critical thinking on how to solve problem in the organization. Thirdly skills and competent a person must be skillful, equipped and knowledgeable of those necessary skills needed in the industry. Aside of education you must have creativity and innovativeness in managing a business. according to Wessel that the universities and colleges has play a big role in enhancing the skills of the students by proving a good training outcome based or skills based curriculum would be a plus factor for them to be ready and have an easy access working in the industry. Furthermore, the last factor that a student must acquire are customer service, financial management and crisis management these four factors are very vital skill in becoming a good leader someday in an organization because these factors will be your driving force in facing the possible challenges in the company. He also added that incorporating the education and experience would an excellent combination that would mold you as early as young age so that when you enter in the workforce of the society it would be easy for you to compete with those senior age.

Miranda (1999), conducted a study on the level of competency needed by the hospitality industry, where respondents are both male and female in his findings HR recruitment still prefer those applicant who possess the six most important skills needed when entering the industry education, industry experience, employee relations skill, leadership skill, guest services skills and conflict management. For education he found that respondents were rated very important as it will be cutting edge to succeed in the industry. If you have education would be easy for to speak the language of business and to manage a critical situation. Working experience was also rated very important, that if you have experience, chances are you will be able to master the skills and familiar the daily activities, therefore it would easy for you to design a good strategy on how to win in the business. Another advantage is having an employee relationship, leadership, guest service and conflict management which was rated very important, it is blatant that the industry approve that these skills are necessary to have, an individual must acquire these important skill in order to be resilient $I$ in any situation of the business. According to Pablo promotion standard must require tough qualification in order to ensure that the person is really qualified for the position and not just a waste of time.

In the previous Chen Nian. ET. Al ( 2014) effect of competency at work on job satisfaction and organizational commitment in the restaurant he found out that study of This study empirically tested the relation between the individual competencies of employees in the foodservice industry, as core competencies that improve the competitiveness and effectiveness of the foodservice industry, and job satisfaction and organizational commitment, which are an organizational achievement. Based on this concept, it attempted to achieve the following academic purposes; first it provided more detailed individual competency factors related to job satisfaction; second, it aimed at offering a depth of information to restaurant industry as well as restaurant employees. For current restaurant employees, they can carry out self-evaluation based on the result of this study. The results of current study revealed that three factors of individual competency highly predict commitment by explaining $74 \%$ of the variance. In particular, the individual competency factor impact \& influence, managerial, personal effectiveness are significant predictor of which in turn relates to job satisfaction and this information can help the restaurant employees to identify what essential competencies are missing. In addition, the study will aim to provide the basic data required for developing an ability-based curriculum for universities. Furthermore, it aims to understand the degree of current awareness in the foodservice industry of the importance of the individual ability factors of expert employees in the industry, and examine whether or not the factors affect job satisfaction and organizational commitment. However, it is hard for the universities with this ideal purpose to educate and develop students and help them to get jobs in the foodservice industry. Worse still, even when graduates from such programs find employment, they tend to easily give up on their work. As there has been a gap between the competencies that the foodservice industry demands and those that students have cultivated at university, the ideal balance is hard to achieve. Thus, to respond to the rapid growth of the foodservice industry, university education should cover comprehensive and practical methods that can increase the competencies of the 13th Asia Pacific Forum for Graduate Students Research in Tourism students, instead of simply delivering and teaching traditional knowledge and skills. In this situation, the ability-based curriculum in the recent educational course design model has been attracting attention. To put it simply, this is a method in which preferentially required competencies are understood in developing the curriculum and an attempt is made to develop the curriculum that helps the students learn the essential competencies. The analysis study on the curriculum of foodservice management major emphasized that the undergraduate curriculum should be planned based on the competencies required for managers. This study has some limitations that may be addressed in future studies. This study focused on restaurant employees in Korea only. While this allows for more nation-specific control, The ability to generalize the outcomes of the study outside of Korea within the industry is limited. For future studies, cross-national studies is recommended for better understanding of individual competency and organizational performance.

Similar in the study of Liaman (2014) the objective was met by study that identified that as for managers, 22 out of 31 managers surveyed were males which are almost $71 \%$ of the whole target group. 
Most of the managers were in between the age range $31-40(55 \%)$ finding revealed that $60 \%$ of the workforce were women, which is 25 out of 42 respondents. The findings revealed that mostly of the middle level position $(55 \%)$ had a bachelor degree holders, while it was observe that only $4(13 \%)$ manager has Tourism and hospitality graduate, aside from that there were managers who are just a high school graduate. $70 \%$ of the respondent shad past working experience in the hotel and tourism industry.

As far the result young respondent group with just a secondary background, while 24 out 42 have bachelor or master's degree holder. Other goal was set to find if hotels and hostels in Prague offer any qualification development trainings and how efficiently they effect in overall performance of the employee within the company. This question was related only to managers, therefore as it has been surveyed (see Appendix B, question 11, 12, 13, 14, 15), out of 21 hospitality establishments only 16 (76.19\%) offer qualification development trainings; 13 out of 16 establishments are hotels and 3 are hostels. In fact 14 (87.5\%) out of 16 hospitality establishments that provide trainings, completely cover all expenses that are required for training, such as payment for the training time, training materials and travel expenses. Remaining 2 (12.5\%) hospitality establishments partially cover some expenses, as for example, paying employee half of the regular wage during the training hours. The frequency of trainings is stable for all 16 hospitality establishments, as nearly $100 \%$ managers indicated that qualification trainings take place only once a year. This does not relate to entry-level trainings as they take place every time when a new employee is hired. The fifth objective was to determine whether hotels and hostels in Prague offer real career growth opportunities. Question related to this objective was also directed only to managers of hostels and hostels. In fact, not all hospitality establishments offer career path development plans. The career path development opportunity will be offered in 19 out of 21 hospitality establishments if hospitality establishment has: enough qualified employees and confidence that employee will stay within the company for a long time. In cases if hospitality establishment prefers hiring new people for the vacant positions in order to avoid extra expenses or generally has low retain ability of employees, the career path development will not take place. For more detailed explanation see Table 7. The objective six was set to highlight and analyze the main reasons employees are being fired for or quit. This question was addressed both managers and employees and results showed that the first three reasons why an employee might get fired by manager are: inability to fulfill the responsibilities, low level of customer service and bad relationship with colleagues. On the other hand, employees named three main reasons what would make them quit the job, which are: bad or not developing position in the company, unfriendly colleagues and unfriendly supervisor or CEO. As it was clear from the survey for employees the atmosphere at work play a bigger role than to the managers, in fact 2 out of 3 reasons were regarding colleagues at work. Detailed breakdown of the results can be found in Table 8 . The seventh objective was set to identify what top 5 qualities of the employee do the hospitality establishments in Prague usually looking for. The answer to this objective was given through the competency model of Chung-Herrera, Enz and Lankau (2003) that was presented to employees. They were asked to rank the competencies from the most important to the least important on 1 to 5 scales. The results for this objective can be found in the Table 10. The eights objective was to identify the main qualities, competencies and skills for the best performance at work, from the employer and employee point of view. In order to meet this objective, results of two competency modeling tables were combined together to represent opinions of managers and employees.

\section{METHODOLOGY}

The study was adopted a descriptive survey, as the main tool in gathering the data. The researcher created a self-made questionnaire for the investigation. The questionnaire has a four important phases in order to extract an accurate information namely; training and development in which criteria will determine how many times that the employee attended in a training every month, year and if is relevant to their work. Second phase is work experience which will measure if the employee has a previous work related from his job and the number of year being in that work. Third phase the attitude and personality of an individual towards work which will sees how an individual will follow the policy and his understanding towards his work in general, and lastly is education which emphasize a type of education acquired by an employee and it's important on how to play his role in a managerial position.

The respondent of the study were 100 employees who are currently working a hospitality an d 1 year in service, this type of criteria of respondents were chosen because the researcher believe that they have enough knowledge on how to answer the questionnaire and give an accurate information, which is very important for the study.

Permit to administer the questionnaire was approved by the managers of the chosen facility, the researcher administered the tool to the chosen respondent, collected, and tallied, tabulated and descriptive analysis were used.

\section{RELIABILTIY AND VALIDITY OF MEASSURE}

The four phases of competencies namely; training and development, work experience, attitude and personality and education, were independently evaluated using the statistical formula. For accuracy and precise interpretation and analysis of the findings, the following statistical tools were used:

Mean. This were used to determine the importance competency skills and training needs as assessed by the full-time employees of the selected hotels and restaurants The formula is presented below:

$$
\mu=\frac{\Sigma f X}{n}
$$

where:

$\mu=$ weighted mean

$\Sigma=$ Summation

$f=$ the number of responses under each scale

$X=$ the weight assigned to each scale

$n=$ Number of respondents 
Competency-Based Skills and Training Needs of Hotel and Restaurant Employees towards Key Position in Muscat, Oman: An Inquiry to the Customer

\section{RESULTS AND DISCUSSION}

Table 1: Respondents gender profile

\begin{tabular}{|l|c|c|}
\hline \multicolumn{1}{|c|}{ Gender } & Frequency & Percentage \\
\hline Male & 50 & $50 \%$ \\
\hline Female & 50 & $50 \%$ \\
\hline Total & 100 & $100 \%$ \\
\hline
\end{tabular}

Table 1 displayed the gender profile of the respondents. As shown in the table, 50 or $50 \%$ of the respondents were males and 50 or 50 percent of the respondents were females. There were total of 100 respondents of this study. The distribution of gender among of the respondent were considered because of its deferent point of view, preference and quality. Thus, gender segregation is vital in order to get an accurate information

Table 2: Respondents age profile

\begin{tabular}{|l|c|c|}
\hline \multicolumn{1}{|c|}{ Age } & Frequency & Percentage \\
\hline $20-30$ & 50 & $50 \%$ \\
\hline $31-40$ & 30 & $305 \%$ \\
\hline 47 - above & 20 & $20 \%$ \\
\hline Total & 100 & $100 \%$ \\
\hline
\end{tabular}

Table 3 shows the age profile of the respondents. As a disclosed in the table $250 \%$ of the respondents claimed that they were in the age bracket of 25-35 years old while $30 \%$ of the respondents claimed that they were in the age bracket of 36- 46 years old and lastly $20 \%$ of the respondents claimed that they were in the age bracket 47 years old above.

Table 3: Summarized table of training/development $(n=100)$

\begin{tabular}{|c|l|c|c|}
\hline \multicolumn{2}{|c|}{ Indicators } & $\begin{array}{c}\text { Factor } \\
\text { Mean }\end{array}$ & Interpretation \\
\hline 1 & $\begin{array}{l}\text { Training and } \\
\text { development program } \\
\text { attended }\end{array}$ & 3.45 & $\begin{array}{c}\text { Very } \\
\text { Important }\end{array}$ \\
\hline 2 & $\begin{array}{l}\text { Frequency of attending } \\
\text { training program }\end{array}$ & 3.46 & $\begin{array}{c}\text { Very } \\
\text { Important }\end{array}$ \\
\hline 3 & $\begin{array}{l}\text { Benefits of training } \\
\text { programs }\end{array}$ & 3.39 & Important \\
\hline & Over-all weighted mean & $\mathbf{3 . 4 3}$ & $\begin{array}{c}\text { Very } \\
\text { Important }\end{array}$ \\
\hline
\end{tabular}

Table 3 shows the summarized data of the importance of the different category of training and development. In which employee must have or acquired in early stage of their career or while working in the hospitality industry. Acquiring training and development were generally rated as 3.45 or very important, which depicts that in order for you to be completive for the promotion you must have acquire a training certificates and upgraded your knowledge thru training. While the respondents agreed that frequency of attending training program is very important with the ratings of 3.46, by attending training programs in a weekly, monthly or yearly basis is a requirement for every individual as it will help them to hone their skill and update their knowledge in order to advance their performance. Respondents also agreed that the benefits of Training programs with 3.39 or important. with the overall weighted mean of 3.43 or very important, Respondents therefore concluded that training and development is one of the important tool to improve, make your knowledge up to date and ready for any changes of standard within the organization.
Table 4: Summarized table of work experience $(n=100)$

\begin{tabular}{|c|l|c|c|}
\hline \multicolumn{2}{|c|}{ Indicators } & $\begin{array}{c}\text { Factor } \\
\text { Mean }\end{array}$ & Interpretation \\
\hline 1 & $\begin{array}{l}\text { Previously work as } \\
\text { manager of hotel and } \\
\text { restaurant }\end{array}$ & 3.45 & Very Important \\
\hline 2 & Own a related business & 3.41 & Very Important \\
\hline 3 & $\begin{array}{l}\text { Previously working } \\
\text { abroad or outside the } \\
\text { country }\end{array}$ & 2.55 & $\begin{array}{c}\text { Less } \\
\text { Important }\end{array}$ \\
\hline 4 & $\begin{array}{l}\text { Experience as on-job- } \\
\text { training }\end{array}$ & 3.40 & Important \\
\hline & $\begin{array}{l}\text { Over-all weighted } \\
\text { mean }\end{array}$ & $\mathbf{3 . 2 0}$ & Important \\
\hline
\end{tabular}

Table 4 displayed the summarized data of the type of work experience that an employee must have before promotion. Respondent rated as 3.45 or very important on the previously work as a manager of hotel and restaurant, thus to have a background in a related industry would be a plus factor because you will have the ability to familiarized the nature of the jog and the mastery of skills. While majority of the respondents believe that to own a related business is very important which was rated 3.41, Therefore, by owning a the same business is a concreate and credible exposure which gives an individual an early understanding about management operation, challenges and opportunities, which gives an opportunity to be a successful manager. While experience working has play a less factor in advancing to a managerial position which was generally rated 2.55. Although experience as on-job training was rated 3.40 or important it is imperative that even in a short period of time an individual must at least exposure to the job nature. An overall weighted mean of 3.20 or important was rated by majority of the respondents, experience in working into related job would help you to bring the best in you and support your knowledge on how to perform your job.

Table 5: Summarized table of attitude and personality $(\mathrm{n}=100)$

\begin{tabular}{|c|l|c|c|}
\hline \multicolumn{2}{|c|}{ Indicators } & $\begin{array}{c}\text { Factor } \\
\text { Mean }\end{array}$ & Interpretation \\
\hline 1 & $\begin{array}{l}\text { Time management aspect } \\
\text { towards work }\end{array}$ & 3.45 & $\begin{array}{c}\text { Very } \\
\text { Important }\end{array}$ \\
\hline 2 & Qualities and values & 3.44 & $\begin{array}{c}\text { Very } \\
\text { Important }\end{array}$ \\
\hline 3 & $\begin{array}{l}\text { Relationship among } \\
\text { employees }\end{array}$ & 3.47 & $\begin{array}{c}\text { Very } \\
\text { Important }\end{array}$ \\
\hline & Over-all weighted mean & $\mathbf{3 . 4 5}$ & $\begin{array}{c}\text { Very } \\
\text { Important }\end{array}$ \\
\hline
\end{tabular}

Table 5 shows the summarized data of the attitude and personality as one the important factor for promotion, in order for you to be wise enough and easily to adopt the very challenges in the organization you must have a desirable attitude and personality. In time management aspect which was generally rated 3.45 or very important, therefore to be a time oriented person is empirical for a good leader and improving the quality of your work. 
It will determine your speed in finishing your work which play a very important role in time management. likewise qualities and values was rated 3.44 or very important, according to the respondents having a good values or behavior it would be easy for you to please your staff and create a good camaraderie, which build teamwork and motivation to all employees. Having a good relationship among of the co-employees was rated 3.47 or very important, harmony and easy to work with are important to practice, because of this it will help them to support each other, working together to achieve the vision and mission of the organization. The general weighted mean is 3.45 or very important, therefore this factor is always a must to all employees' harmony and motivation will only achieve in everyone has a good relationship.

Table 6: Summarized table of education acquired $(n=100)$

\begin{tabular}{|c|l|c|c|}
\hline \multicolumn{2}{|c|}{ Indicators } & $\begin{array}{c}\text { Factor } \\
\text { Mean }\end{array}$ & Interpretation \\
\hline 1 & $\begin{array}{l}\text { Attended formal education } \\
\text { such as; (baccalaureate, } \\
\text { master and doctorate } \\
\text { degree) }\end{array}$ & 3.50 & $\begin{array}{c}\text { Very } \\
\text { Important }\end{array}$ \\
\hline 2 & Acquired diploma degree & 3.43 & $\begin{array}{c}\text { Very } \\
\text { Important }\end{array}$ \\
\hline 3 & $\begin{array}{l}\text { Attended short courses, } \\
\text { trainings and seminars }\end{array}$ & 3.42 & $\begin{array}{c}\text { Very } \\
\text { Important }\end{array}$ \\
\hline & Over-all weighted mean & $\mathbf{3 . 4 5}$ & $\begin{array}{c}\text { Very } \\
\text { Important }\end{array}$ \\
\hline
\end{tabular}

Table 6 displays the summarized data on the relevance of acquiring good education in improving the skills competency, Attended a formal education were rated 3.50 or very important which means if an employee attended a diploma or any formal education is an advantage because he or she would likely competent and knowledgeable, likewise acquiring a diploma degree rated 3.43 or very important same formal education but this form a short course like two year program, the advantage of it is an employee ha an advance concept on the operation and system must be implemented as it will be taught in the school, and attending short courses, trainings and seminar were also rated 3.42 or very important and lastly the overall weighted mean was 3.45 or very important therefore education is likely to increase managerial advancement as it provides the knowledge, skills and credibility for performance in high level positions. It is likely to lead self-initiated training and to offers of training made because those who sanction training have more confidence it will be successful with educated people.

Table 7: Summarized data on the importance of competency skills, training needs of hotel \& restaurant employees towards key position $(n=100)$

\begin{tabular}{|c|l|c|c|}
\hline \multicolumn{2}{|c|}{ Competency } & $\begin{array}{c}\text { Factor } \\
\text { Mean }\end{array}$ & Interpretation \\
\hline 1 & $\begin{array}{l}\text { Training and } \\
\text { Development }\end{array}$ & 3.43 & Very Important \\
\hline 2 & Work Experience & 3.20 & Important \\
\hline 3 & $\begin{array}{l}\text { Attitude and } \\
\text { Personality }\end{array}$ & 3.45 & $\begin{array}{c}\text { Very } \\
\text { Important }\end{array}$ \\
\hline 4 & Education & 3.45 & Very Important \\
\hline & General mean & $\mathbf{3 . 3 8}$ & Very Important \\
\hline
\end{tabular}

Table 7 displayed the importance of competency skills and training needs of the hospitality employees, based on the findings. Training and development were generally rated as very important or 3.43 , which means attending training is very empirical for managerial position which make you skill strong and up to date, which will help your readiness and preparedness to innovate and initiate new things in the organization. In terms of work experience generally rated 3.20 or important which means acquiring work experience in a related industry is a big much of help for you to familiarize the different functions and challenges in the organization. The attitude and personality was generally rated 3.45 as very important which will drive to success in handling people, motivates them and support an encourage them to build a good relationship is one of the most important factor as a manager. While education generally rated 3.45 or very important having a good an education as a future leader will support your critical analysis especially in solving some critical issue in the organization. With the general mean of 3.38 or very important. These factors encourage to those aspirant leaders, therefore he or she must be prepared not only the skills but also his attitude in to be more effective in managing an operation. And lastly education was rated as very important 3.45 degree is big contributory factor in advancing into top management level, since you have the foundation of theoretical knowledge and techniques which taught in a formal education, it would support you in executing those knowledge in the real scenario, those theory will guide you the exact procedures to become a leader.

\section{CONCLUSION AND RECOMMENDATION}

In a dynamic business society with full of work-force competition each individual must be ready and equipped themselves in enhancing their competencies and skills by acquiring trainings, education, work experience and mostly must possess a good attitude are the most important elements in order to advance in a key position in the hospitality industry. The result of the findings indicated that trainings and development, education work experience and attitude are the most important and effective tools which help the employee to be on top position, it gives an opportunity to those working in a hotel and restaurant facilities to upgrade their competencies and skills for a sustainable career growth.

Furthermore, it is highly recommended to those who are currently working and those who plan to work in the said facility to continue strive hard by attending trainings and acquire education to strengthen their knowledge and hone their skills by getting good working opportunity in hotel and restaurant business.

\section{REFERENCES}

1. Boyatzis, R. (1982). The Competent Manager: A Model for Effective Performance. New York: John Wiley \& Sons.

2. Bueno, C. and Tubbs, S. (2004). Identifying Global Leadership Competencies: An Exploratory Study. Journal of American Academy of Business, 5(12), pp. 80-87.

3. Carretta, A. (1992). Career and Succession Planning. In Mitrani, A., Dalziel, M., and Fitt, D. Competency Based Human Resource Management. HayGroup, 1992.

4. Christine Adhiambo Odhiambo. "Social Media as a Tool of Marketing and Creating Brand Awareness: Case Study Research". A thesis presented to Department of Business Administration, Vaasan Ammattikorkeakoulu University of Applied Sciences. Vaasa, Finland, 2012. 
5. Dubrin, A. Leadership: Research Findings, Practice, and Skills, Published:Cengage Learning, Inc. Florence, USA, 2016.

6. Georgios Tsimonis Sergios Dimitriadis. "Brand strategies in social media", Marketing Intelligence \& Planning, Vol. 32 Issue 3, 2014, pp. $328-344$

7. Gould-Williams, J. "The Importance of HR Practices and Workplace Trust in Achieving Superior Performance: A Study of Public-Sector Organizations". International Journal of Human Resource Management, 2003, pp. 28-54.

8. H B Tritama and R E Tarigan. "The Effect of Social Media to the Brand Awareness of a Product of a Company", CommIT Journal, vol. 10, no. 1, 2016, pp. 9-14.

9. Icha Oyza, Agwu M. Edwin, "Effectiveness of Social Media Networks as a Strategic Tool for Organizational Marketing Management”. J Internet Bank Commerce S2:006, 2015.

10. Jacob, Ronal L. Structured On-The-Job Training. Berrett-Koehler Publishers, 2003.

11. Kay, C., \& Moncarz, I. "Knowledge, skills, and abilities for lodging management success". Cornell Hotel and Restaurant Administration Quarterly, vol. 45 no. 3, 2004, pp. 285-298. Retrieved September 2004 from ProQuest database.

12. Leech, N., Barrett, K., \& Morgan, G. SPSS for intermediate statistics: Use and interpretation, 2nd edition. Mahwah, New Jersey: Lawrence Erlbaum Associates Publishers, 2005.

13. Liaman, A. (2014). Competencies and Qualification of Staff and Management in Hospitality Establishment: Dissertation, Institute of Hospitality Management in Prague.

14. Manoj Timilsina. Impacts of Social Media Restaurant business: A case Study Based on Oulu Region, 2017 https://www.theseus.fi/bitstream/handle/10024/128861/Timilsina_Man oj.

15. McCourt, W. \& Derek, E. Global Human Resource Management: Managing People in Developing and Transitional Countries. Cheltenham, UK: Edward Elgar, 2003.

16. Mohammad Reza Nemat Gorgani. "The Impact of Social Network Media on Brand Equity in SMEs". European Journal of Sustainable Development, vo. 5, no. 3, 2016, pp. 239-244.

17. Nian Chen (2014), Effect of Competency at Work on Job Satisfaction and Organizational Commitment in the Restaurant Industry, Researchgate, : https://www.researchgate.net/publication/313401141,

18. Quinn, P., Faerman, S., Thompson, M., \& McGrath, M. Becoming a master manager: A competency framework, (3 rd. ed.). Hoboken, NJ: John Wiley and Sons Inc, 2003.

19. Rao, T.V. Human Resource Development - Concept and Background, Human Resources Development: Experiences, Interventions and Strategies, New Delhi: Sage Publications, 2000.

20. 19) Rodrigues, L. L. R., \& Chincholkar, A. M. "Benchmarking the HR Practices of an Engineering Institute with Public Sector Industry for Performance Enhancement". International Journal of Training and Development, vol. 9:1, 2005, pp. 6-20.

21. Orser, B. Management competencies and SME performance criteria: A pilot study. Industry Canada, 2003. Retrieved September 22, 2004 from http://strategis.ic.gc.ca/epic/internet/insbrprppe.nsf/en/rd00854e.html.

22. Miranda, Pablo. (1999). The Level of Technical Skills and Management Competency Demanded by the Hospitality Industry as Perceived by Hospitality Recruiters. Dissertation, University of Wisconsin_Stout.

23. Paquette, Holly. "Social Media as a Marketing Tool: A Literature Review”, Major Papers by Master of Science Students. Paper 2, 2012 http://digitalcommons.uri.edu/tmd major_papers/2.

24. Purcell Kate, (1993), Equal opportunities in the hospitality: custom and credentials, International Journal of Hospitality Management, Vol. 12, (2).

25. Roxanne Debono. "The effectiveness of Social Media Marketing as a Branding tool for hoteliers". A thesis presented to Institute for Tourism, Travel \& Culture.University of Malta, Msida, Malta, 2013.

26. Sandwith, P. "A hierarchy of management training requirements: The competency domain model". Public Personnel Management, vol. 22 no. 1, 1993, pp. 43-62. Retrieved March 2006 from EBSCO database. Tas, R. (1983). Competencies important for hotel manager trainees. University Microfilms International, (8414189).

27. Shalaka Ayarekar. "Impact and Effectiveness of Social Media Advertising on Young Working Women's Buying Behaviour With Reference to Consumer Electronics" - A Study of Selected Cities in Maharashtra and Gujarat. A dissertation presented to Department of Business Management, D. Y. PATIL UNIVERSITY, Mumbai, India.

28. Stein, Joshua."The Relationship Between Social Media Use and Consumer Brand Engagement", Journal of Undergraduate Research at Minnesota State University, Mankato: Vol. 12, Article 11, 2012.
29. Thoene, Whitney Sue. "The Impact of Social Networking Sites on College Students' Consumption Patterns", Theses, Dissertations and Capstones. Paper 245, 2012.

30. Tina Vukasovič. "Building successful Brand by Using Social Networking Media". Journal of Media and Communication Studies. Vol. 5 no. 6, 2013, pp. 56-63, July, 2013.

31. United Nations Industrial Development Organization. (2002). UNIDO Competencies. http://www.unido.org.

32. Weil, A., \&Woodall, J. "HRD in France: the corporate perspective". Journal of European Industrial Training, vol. 29, no. 7, 2005, pp 529-540.

33. Wessels, W., (2017). Key competencies and characteristics of accommodation managers. SA Journal of Human Resource Management, 15, 1-11. doi: https://doi.org/10.4102/sajhrm.v15i0.887.

34. Woodruffe, C. What is Meant by Competency? In: Sparrow, P.R., Boam, R., Eds. Designing and Achieving Competency. McGraw-Hill International.UK, 1992.

\section{AUTHOR PROFILE}

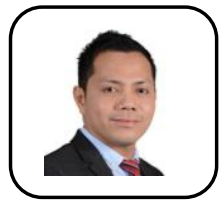

Roland Getaruelas is $\mathrm{PhD}$ in Business Administration from University of San Jose-Recoletos, Philippines and Master of Business Management from University of San Jose-Recoletos, Cebu City, Philippines. His field of interest includes Marketing, Human Resource Management, Consumer Behavior and Entrepreneur, etc. 